\title{
The transportation of bigamists in early nineteenth-century England and Wales
}

\section{Rebecca Probert and Liam D'Arcy-Brown}

\begin{abstract}
Between 1795 and 1853, over 250 men and women were sentenced to transportation for committing the crime of bigamy. This harsh treatment is at odds with the assumption that the sentences handed down to bigamists were generally light. This article provides the first in-depth study of the use of transportation in this context, drawing on the criminal registers, the Proceedings of the Old Bailey, and local and national newspaper reports in order to ascertain who was transported for bigamy, and why. Analysing a range of aggravating and mitigating factors, it shows why certain cases were deemed to merit the harshest form of punishment, while others, despite exhibiting some of the same factors, were treated more leniently. The sheer greed, deceit and nastiness demonstrated by many of these bigamists provides a significant counter-narrative to the depiction of bigamy as a substitute for divorce and raises broader questions about its incidence.
\end{abstract}

Keywords: bigamy; transportation; Old Bailey

\section{INTRODUCTION}

In October 1798, a man named John Wheeler pleaded guilty to bigamy at the Old Bailey. ${ }^{1}$ Somewhat surprisingly, the court was reluctant to accept his plea. The Common Serjeant

\footnotetext{
${ }^{1}$ Proceedings of the Old Bailey (hereafter OBP, or the Proceedings), 14 Oct. 1798.
} 
told him that bigamy was the crime that more than any other 'afforded room either for mitigation or aggravation, according to the circumstances'. ${ }^{2}$ Every effort was exerted to make him change his plea so that all the evidence could be heard and taken into account in the sentence. ${ }^{3}$ Given a day to think it over, John did indeed change his mind and pleaded not guilty. Alas, his original prediction that he 'was sure of being convicted' proved accurate. ${ }^{4}$ According to the reports in the newspapers, after abandoning his first wife (a 'beautiful young girl of sixteen') in 1776, he had married a second, who was in receipt of a small annuity; a third he had 'seduced from a boarding school at Lambeth' and the last was the sixteen-year-old 'daughter of a respectable tradesman' ${ }^{5}$ He had finished by running off with the mother of his latest wife, ${ }^{6}$ or, as the Observer described in horrified terms, 'one of his children's Grandmother! ${ }^{77}$ He had further aggravated his bigamy by cruelty, having 'behaved extremely ill to all his wives except the last' ${ }^{8}$ Nor did he even have the excuse of being under any misapprehension as to the law: as counsel noted, his criminality was compounded by the fact that he had been 'originally placed in a genteel stile of life, and received a liberal education, which should have taught him better'. ${ }^{9}$ His

\footnotetext{
${ }^{2}$ True Briton, 25 Oct.1798.

${ }^{3}$ London Chronicle, 23-25 Oct. 1798.

${ }^{4}$ Ibid.

${ }^{5}$ Oracle and Daily Advertiser, 26 Oct. 1798; London Chronicle, 1-3 Nov. 1798.

${ }^{6}$ Whitehall Evening Post, 25-27 Oct. 1798; Oracle and Daily Advertiser, 26 Oct. 1798.

${ }^{7}$ Observer, 28 Oct. 1798.

${ }^{8}$ Observer, 11 Nov. 1798.

${ }^{9}$ Oracle and Daily Advertiser, 26 Oct. 1798. According to the London Chronicle, 1-3 Nov. 1798 he had studied at Oxford.
} 
case was described in the press as one of the most 'aggravated and malignant' ever to come before the courts, ${ }^{10}$ and he was sentenced to seven years' transportation.

Wheeler's case was an exceptional one. Yet it is nonetheless important in illustrating a number of broader trends. While he was only the second person to be sentenced to transportation for bigamy following legislation in 1795 that had sought to increase the potential punishment for the offence, ${ }^{11}$ in the decades that followed hundreds more convicted bigamists were to suffer a similar fate. This stands in sharp contrast to the claim that sentences for bigamy were "notoriously light"12 in the first half of the nineteenth century. Pamela Sharpe, for example, makes no mention of transportation in her study of bigamy in Essex between 1754 and 1857, suggesting instead that 'the penalties were not severe... bigamy seems to have been treated leniently by the

\footnotetext{
${ }^{10}$ Lloyd's Evening Post, 26-29 Oct. 1798.
}

11 The first had been Thomas Shuttlewood: OBP, 6 April 1796.

${ }^{12}$ Ian Ward, Sex, Crime and Literature in Victorian England, Oxford, 2014, 70. See also Colin Gibson, Dissolving Wedlock, London, 1994, 52, claiming that ' $[\mathrm{t}]$ hose who were detected and prosecuted often received judicial clemency'. 
authorities'. ${ }^{13}$ Stephen Parker similarly notes that 'there is a suggestion that sentences were quite lenient' ${ }^{14}$

This impression of leniency has been encouraged by the relative neglect of bigamy in general histories of the criminal law $^{15}$ and by the paucity of specific studies of bigamy for this particular period. ${ }^{16}$ Colwell's short article focuses on the utility of criminal records as a source for genealogists: while she notes the number of bigamy cases at the Old Bailey that resulted in transportation, she does not analyse what kinds of cases these were. Ginger Frost, in a detailed analysis of 304 bigamy cases occurring between 1760

${ }^{13}$ Pamela Sharpe, 'Bigamy among the Labouring Poor in Essex, 1754-1857' Local Historian (1994), 139, 140. In fact, of the 29 people convicted of bigamy in Essex between 1806 and 1856, six (21 per cent) were transported, all of them for seven years. Sharpe's sample of cases seems to be drawn primarily from bigamies involving the poor law, which did not necessarily lead to prosecution, and her focus is on why individuals committed bigamy rather than sentencing patterns. Interestingly, the one bigamist whose sentence she does record-William Goulden-was given two years, which does not seem particularly light.

${ }^{14}$ Stephen Parker, Informal Marriage, Cohabitation and the Law, 1750-1989, Basingstoke, 1990. However, his cited source in fact stated that 'the Court was not always lenient': S Colwell, 'The Incidence of Bigamy in 18th and 19th Century England' Family History, (1980, 91.

${ }^{15}$ Bigamy does not appear in the index to Leon Radzinowicz's monumental A history of English criminal law and its administration from 1750 (five volumes published between 1948 and 1986, the last with Roger Hood). Nor does it feature in more recent works such as Norma Landau (ed), Law, Crime and English Society, 1660-1830, Cambridge, 2002, Peter King, Crime and Law in England, 1750-1840, Cambridge, 2006, Alan Norrie, Crime, Reason and History: A Critical Introduction to Criminal Law, Cambridge, 3rd ed, 2014, or David J Cox, Crime in England, 1688-1815, London 2014.

${ }^{16}$ For detailed studies of bigamy in earlier periods, see Bernard Capp, 'Bigamous Marriages in Early Modern England' 52(3) The Historical Journal (2009), 537; DM Turner, 'Popular Marriage and the Law: Tales of Bigamy at the Eighteenth-Century Old Bailey’ 30 London Journal (2005), 6. 
and 1914, acknowledges the possibility of transportation in particularly bad cases of bigamy, but her focus is the circumstances in which bigamy was acceptable and she does not deal with the more egregious cases in depth. ${ }^{17}$ Similarly, David Cox notes the possibility of transportation, ${ }^{18}$ but his detailed statistical analysis of bigamy focuses primarily on the period after 1857 , by which time the use of transportation had ceased. The relative lack of attention paid to the possibility of transportation for bigamy, and the wider conclusions drawn from this, make it important to examine these cases in more detail and to recognise them as a significant counter-narrative.

The appalling behaviour of Wheeler also provides a powerful corrective to the type of bigamist more usually depicted in scholarship on divorce reform - that of the poor man tied to a faithless spouse because he was unable to raise the funds to obtain a legal divorce. Much of this scholarship focuses on a single case - that of $R v \mathrm{Hall}$ - and virtually all writers mistakenly claim that Hall was sentenced to a single day in prison, ${ }^{19}$

${ }^{17}$ Ginger Frost, Living in Sin: Cohabiting as husband and wife in nineteenth century England, Manchester, 2008, 74. Given her small sample size, it is unsurprising that she uncovered only eight men being transported in the 1840 s - rather than the fifty-two men and women who were actually transported. Nor does she specifically analyse what led to transportation in these particular cases, or how often transportation featured in her sample of cases.

${ }^{18}$ David J Cox, "'Trying to get a good one”: Bigamy Offences in England and Wales, 1850-1950' Plymouth Law and Criminal Justice Review (2012), 1, 3.

${ }^{19}$ William Searle Holdsworth, A History of English Law Vol. I (London: Methuen \& Co., 1903), p 391; Margaret Cole, Marriage Past and Present, London, 1938, 55-56; Oliver Ross McGregor, Divorce in England: a Centenary Study, London, 1957, 15-16; Lawrence Stone, Road to Divorce, Oxford, 1990, 369; Maureen Waller, The English Marriage: Tales of Love, Money and Adultery, London, 2009, 26262; RB Outhwaite, The Rise and Fall of the English Ecclesiastical Courts, 1500-1860, Cambridge, 
rather than the four months to which he was actually sentenced. ${ }^{20}$ Given the wealth of scholarship on divorce reform in the early nineteenth century, it is perhaps inevitable that this is the story that has prevailed, shaping the impression that sentences were light. Wheeler's case makes it clear that some bigamists behaved badly to both—or all—of their spouses, and were duly punished by the law.

At the same time, Wheeler's case demonstrates how the courts were developing a much more nuanced approach to the offence than had previously been the case. As the words of the Common Serjeant suggest, bigamy was beginning to be seen as an offence that might be more or less serious depending on the facts of the case. With the new availability of transportation for the offence, judges had to decide which cases were deserving of this higher sentence, and which could be dealt with by other means. Wheeler's use of aliases, his multiple marriages, ${ }^{21}$ his seduction of the young, the

2010, 160; Henry Kha and Warren Swain, 'The Enactment of the Matrimonial Causes Act 1857: The Campbell Commission and the Parliamentary Debates' 37(3) Journal of Legal History (2016), 303.

${ }^{20}$ For the other ways in which the details of the case have been misreported see Rebecca Probert, ' $\mathrm{R} v$ Hall and the changing perceptions of the crime of bigamy', 39 Legal Studies (2019), 1.

${ }^{21}$ The exact number of his wives is difficult to ascertain: the Whitehall Evening Post, 25-27 Oct. 1798, made reference to him having had four since his first marriage in 1798, while the Oracle and Daily Advertiser, 26 Oct. 1798, reported counsel for the prosecution as noting that it was only due 'to the moderation of the parties that there were not five charges against him of a similar nature'. The Observer, 28 Oct. 1798, claimed that he had six wives living, and trotted out the by now somewhat hackneyed suggestion that an appropriate punishment would have been to 'condemn him to pass the remainder of his days in the united society of his six helpmates'. Verifying his marriages is complicated by the fact that he used an alias for at least some of them. 
beautiful, and the respectable, ${ }^{22}$ and his desertion of each in turn after ruining them financially, ${ }^{23}$ were all clearly seen as aggravating his offence. But given the number who were sentenced to transportation, it would be surprising if all of them evinced such a range of aggravating factors. It is therefore important to investigate how blameworthy a bigamist had to be in order to receive a sentence of transportation.

The importance of establishing how many individuals were transported for bigamy - and for what reasons - goes beyond ascertaining how the law operated in practice. A key assumption in the scholarship has been that the sentences handed down to bigamists were so light as to be no deterrent at all, and that bigamy was correspondingly common. Stone, for example, suggests that the poor, having 'little or nothing to lose by ignoring the law', developed their own forms of self-divorce and that 'any subsequent act of bigamy carried few serious risks of discovery or of serious punishment if exposed' ${ }^{24}$ In a similar vein, Sharpe, in pondering why couples remarried bigamously at all, suggests that ' $[\mathrm{t}]$ he first reason for contracting a bigamous marriage was that if the crime was discovered, the penalties were not severe' ${ }^{25}$ If we were to find that bigamy was in fact treated much more harshly than has been assumed, then this would have implications for the assumptions that have been made about the incidence of bigamy more generally.

\footnotetext{
${ }^{22}$ Admittedly, not all of the women he was said to have married were all three: the second was described as having been the mistress of a baronet's brother, who was the source of her annuity (London Chronicle, 1-3 Nov. 1798).

${ }^{23}$ The Oracle and Daily Advertiser, 26 Oct. 1798 referred to him 'squandering' the substance of the first wife in dissipation, while the London Chronicle, 1-3 Nov. 1798, claimed that he had ruined his second wife, who was in a Marylebone workhouse as a result.

${ }^{24}$ Stone, Road to Divorce, 21.

${ }^{25}$ Sharpe, 'Bigamy in Essex', 140.
} 
The first task is therefore to establish the impact of the 1795 Act and determine both how many and what proportion of individuals were transported for bigamy. The second is to analyse the circumstances that were likely to lead to an individual being transported. This involves both a careful consideration of the factors that featured in cases that resulted in transportation, and an exploration of why other cases featuring similar factors did not result in transportation. With this information in place, we will show that a number of the assumptions that have been made about bigamy in this period will need to be rethought.

\section{WHAT WAS THE RISK OF BEING TRANSPORTED FOR BIGAMY?}

The ways in which bigamy was punished had varied considerably since it had first been made a crime in 1604 . While the original legislation had made it a felony punishable by death, ${ }^{26}$ no one had been sentenced to death for bigamy since the late seventeenth century. ${ }^{27}$ Branding, which had replaced the death penalty, had also fallen out of favour by the late eighteenth century. At the Old Bailey, the last occasion on which any bigamist had received such a sentence was in 1785 . Legislation in 1779 had enabled the penalty to be commuted to a fine,$^{28}$ and in the decade preceding the passage of the 1795 Act the standard sentence was a year in prison and a one-shilling fine. 1794 saw particularly lenient sentences being handed down at the Old Bailey. Of the six individuals convicted of bigamy, two were sentenced to a year in prison, one to six months, one to two months,

\footnotetext{
${ }^{26} 2$ Jac. II, c. XI. The matter had previously been dealt with by the ecclesiastical courts.

${ }^{27}$ For a detailed analysis of sentencing patterns in this period see Capp, 'Bigamous Marriages'.

${ }^{28} 19$ Geo. III, c. 74. For discussion see Morning Post, 22 Sept. 1779.
} 
one to two weeks, and one to a single shilling. At the assizes the picture was more mixed, with sentences of branding still occasionally being handed down into the 1790 s, but overall sentences were lower than they had been a decade or so earlier.

The perception that bigamy was being treated too leniently_ and was becoming too common ${ }^{29}$ - prompted Mr Alderman Anderson to seek leave in 1795 to bring in a bill 'to increase the punishment of bigamy, to seven years' transportation'. ${ }^{30}$ The resulting legislation ${ }^{31}$ not only changed the way in which bigamy was punished, but also the way in which it was discussed. Whether the punishment for the crime was increased because of a renewed perception that it was a serious offence, or whether the potential punishment led commentators to take it more seriously, counsel, judges, and journalists alike increasingly emphasized the seriousness of the crime and the harm it caused to society. ${ }^{32}$ The perception of its growing frequency also led commentators to call for 'the most exemplary punishment' to be imposed on those convicted. ${ }^{33}$

Throughout the decades that followed, judges regularly made the same point and threatened to impose more severe punishments if they perceived the offence to be

\footnotetext{
${ }^{29}$ As ever, claims as to the frequency of a particular offence need to be treated with a degree of circumspection. While there are as many cases reported in the Proceedings for the years 1790-94 as there are for the previous twenty years, this still only amounted to 22 cases.

${ }^{30}$ St James 's Chronicle, 7-10 Feb. 1795; Whitehall Evening Post, 7-10 Feb. 1795.

3135 Geo. III, c. LXVII.

${ }^{32}$ See e.g. Morning Post and Gazetteer, 24 Sept. 1802, reporting the trial of Edward O'Dannel at the Old Bailey; Morning Post, 14 Aug. 1809, reporting the trial of Philip Facey at the Surrey Assizes; Morning Post, 13 Dec. 1822, reporting the Recorder in the case of Thomas Gibbons as commenting 'in warm terms on the enormity of the offence'; Bury and Norwich Post, 2 April 1828, censuring Garrow for some flippant remarks.

${ }^{33}$ Observer, 2 Dec. 1798.
} 
increasing or to have been dealt with too leniently. Presiding over the Chester Assizes in 1838, Mr Baron Gurney noted that, had the cases in front of him 'presented a little more aggravation', he would have felt it his duty to transport them, since the crime of bigamy was one which judges were determined to put a stop to by making an example of offenders. ${ }^{34}$ The judge who sentenced John Dowling to transportation in 1845 observed that 'he believed that he had been by far too lenient in his judgments' and that this was 'a case that demanded that an example should be made' ${ }^{35}$ In a similar vein, the Common Serjeant, in passing sentence on Thomas Connor at the Old Bailey in 1846, was reported as saying (with a degree of hyperbole, certainly) that

it had long been his opinion that the offence of bigamy had been too leniently dealt with. He knew of no crime that was the means of inflicting more misery upon its victim, and also upon society at large, and he had made up his mind to inflict the punishment of transportation in all cases where parties were convicted of it. ${ }^{36}$

But did the reality follow the rhetoric? If there were a complete absence of reliable statistics for the first half of the nineteenth century (David Cox, for example, observes that reliable criminal statistics 'simply do not exist' before the publication of Judicial Statistics from $1857^{37}$ ), it might be assumed that we have no way of knowing how many cases resulted in transportation. However, Home Office statistics and other official

\footnotetext{
${ }^{34}$ Chester Chronicle, 10 Aug. 1838.

${ }^{35}$ Morning Chronicle, 21 May 1845.

${ }^{36}$ Daily News, 7 July 1846.

${ }^{37}$ Cox, 'Trying to get a good one', 3 .
} 
sources $d o$ exist from which the number of convictions for bigamy in the early nineteenth century - and the number who were transported — can be assessed with reasonable accuracy. From 1805, annual returns of commitments, trials, convictions, and (for most years) sentences were published by order of the House of Commons, ${ }^{38}$ putting figures to the number and outcome of bigamy cases in England and Wales. While the material was presented in different ways at different times - it is sometimes organized by judicial circuit, sometimes by county, and sometimes for England and Wales as a whole ${ }^{39}$-a careful cross-referencing and extraction of data does reward the researcher with annual figures for bigamy convictions and (with some exceptions) sentences of transportation. Combining these findings with the verdicts and sentences recorded in the voluminous

${ }^{38}$ These have now been digitised and are available through the UK Parliamentary Papers database, available to academic institutions subscribing to ProQuest.

${ }^{39}$ Returns detailing the numbers of persons committed, tried, and convicted of all criminal offences were published in most of the years from 1805 to 1855 . Only 1819 and 1852 are not covered at all. Some only give summary totals, but at their most meticulous they specify in fine detail every commitment, trial, outcome, and sentence in every county assize in England and Wales, alongside the numerous boroughs, towns, and cities which had local or separate jurisdiction, and cases heard at general and quarter sessions. Even for the years where sentences are not specified (e.g. 1818 to 1834), the total numbers tried and convicted for bigamy are set out. 
criminal registers produced by each county during the period, ${ }^{40}$ it is possible to assess not only how many individuals were transported for bigamy, but who they were. ${ }^{41}$

Between 1805 and 1853, at least 1,749 men and women were convicted of bigamy, of whom at least 254 were sentenced to transportation. ${ }^{42}$ While women accounted for eighteen per cent of those who were convicted of bigamy in this period, only a miniscule proportion-just 2.8 per cent, representing seven cases-were transported.

The likelihood of a bigamist—male or female — receiving such a sentence did however vary considerably over the period (figure 1). Between 1805 and 1834, a quarter of convicted bigamists were sentenced to transportation, with almost a third (thirty-one per cent) receiving such a sentence between 1815 and 1824. Indeed, at the Old Bailey transportation was the most common punishment for bigamy in the $1810 \mathrm{~s}$, with over half of those found guilty receiving this sentence. After 1835, however, the proportion

${ }^{40}$ The criminal registers are held at The National Archives: Series HO 26 and HO 27. They can also now be found online (behind paywalls) on sites such as Ancestry.co.uk, but are viewable only as digital images of the original handwritten, leather-bound volumes. It is possible to search them by name, but not by offence, and so finding those accused of bigamy was a matter of working through tens of thousands of pages looking for the word 'bigamy' (or occasionally 'polygamy'). The data for this paper was collected from the images available at Ancestry, but references to the original sources are provided for those without access to this site.

${ }^{41}$ The criminal registers contain information on the name, sex, precise sentence, trial venue, and sometimes the age of each individual.

${ }^{42}$ A further eleven cases were identified from the Proceedings and newspaper reports between 1795 and 1804, but in the absence of official returns for this period these have been excluded from the statistical analysis. 
dropped noticeably, with fourteen per cent of convicted bigamists receiving such a sentence between 1835 and 1844, and just five per cent between 1845 and 1853 .

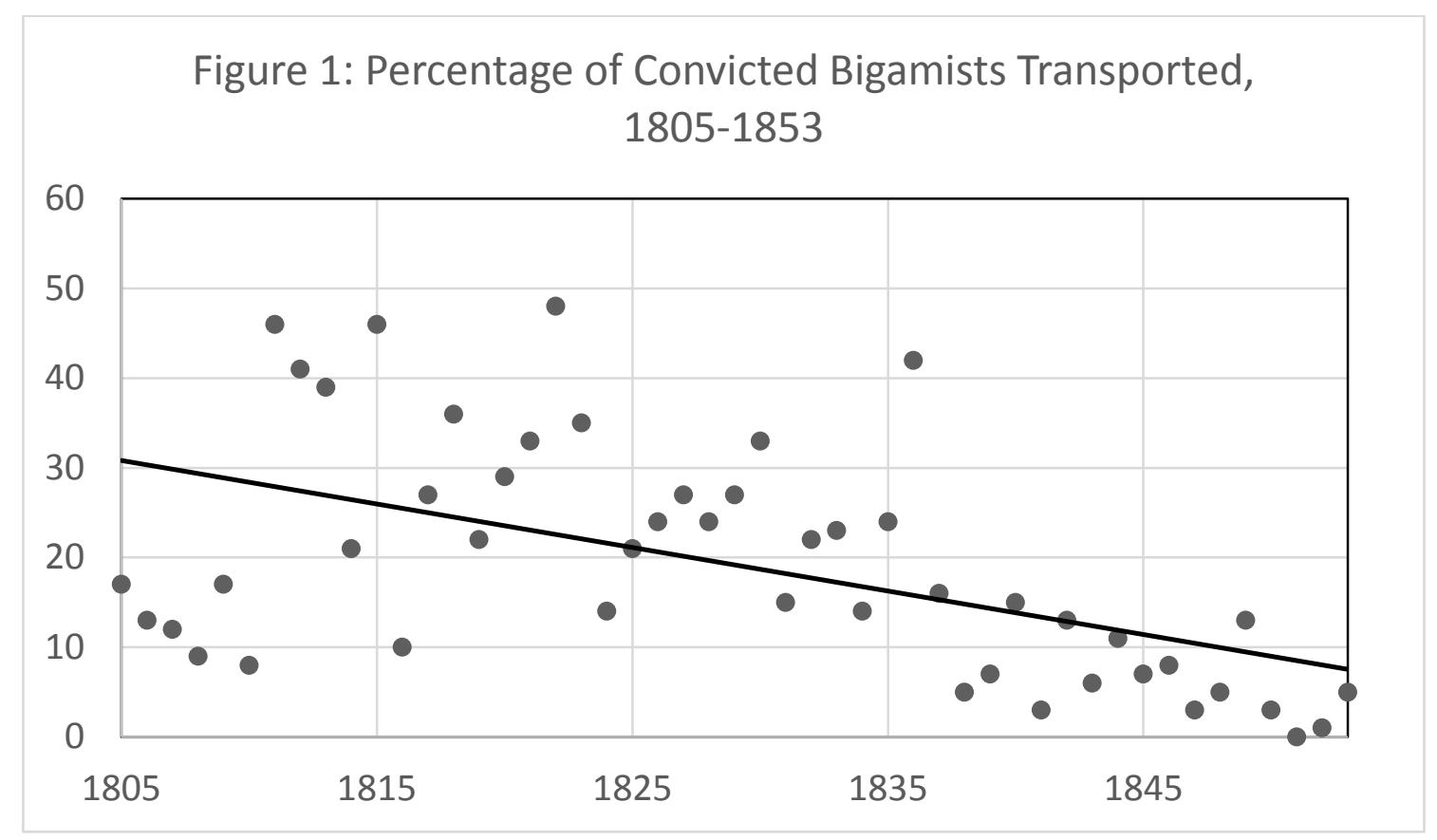

The fall in the percentage of bigamists being transported does, however, need to be set in the context of the increase in the overall number of cases. While there were often quite large fluctuations in the number of cases of bigamy that came before the courts in any given year, the overall trend was very definitely upwards (figure 2). Between 1805 and 1814, an average of seventeen individuals were convicted of bigamy each year; the decade from 1815 to 1824 saw this increase to twenty-three; in the next two decades the annual average climbed to thirty-seven, then to forty-seven, and by the period 1845 to 1853 it had reached sixty-nine. While the population was growing, it was not growing that fast. According to the census, the population of England and Wales grew from 8.32 million in 1801 to 16.81 million in 1851 . In other words, while the population had doubled, the number of convictions for bigamy had more than quadrupled. 


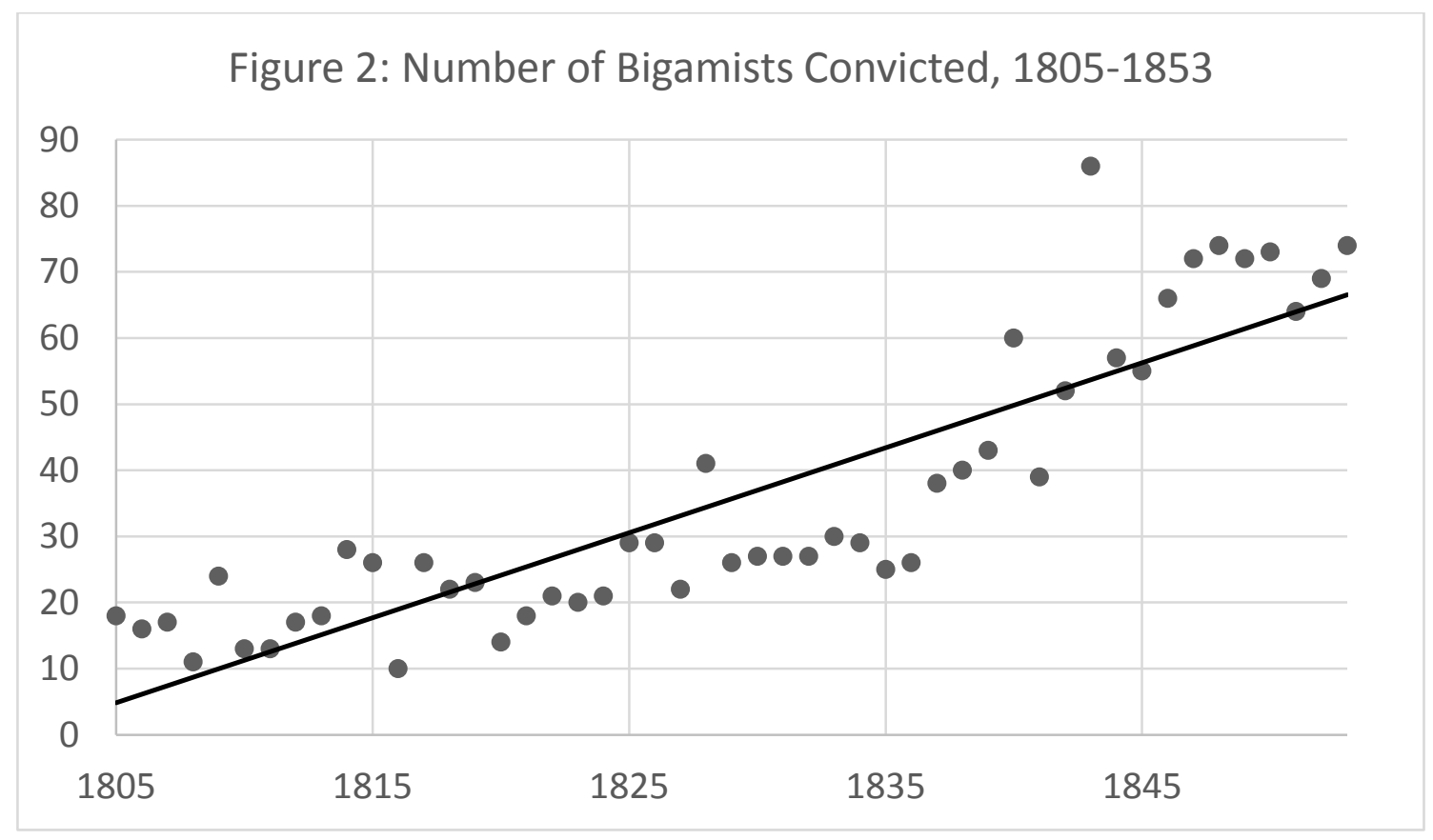

But if we look at the absolute numbers of people sentenced to transportation, a rather different trend emerges. At first sight, these numbers too seem to fluctuate quite considerably, with only one person sentenced to transportation in some years and the numbers climbing into double figures in others. When a linear trend line is calculated and superimposed onto the figures, however, a surprising degree of consistency across the period — roughly five sentences of transportation per year—is revealed (figure 3). 


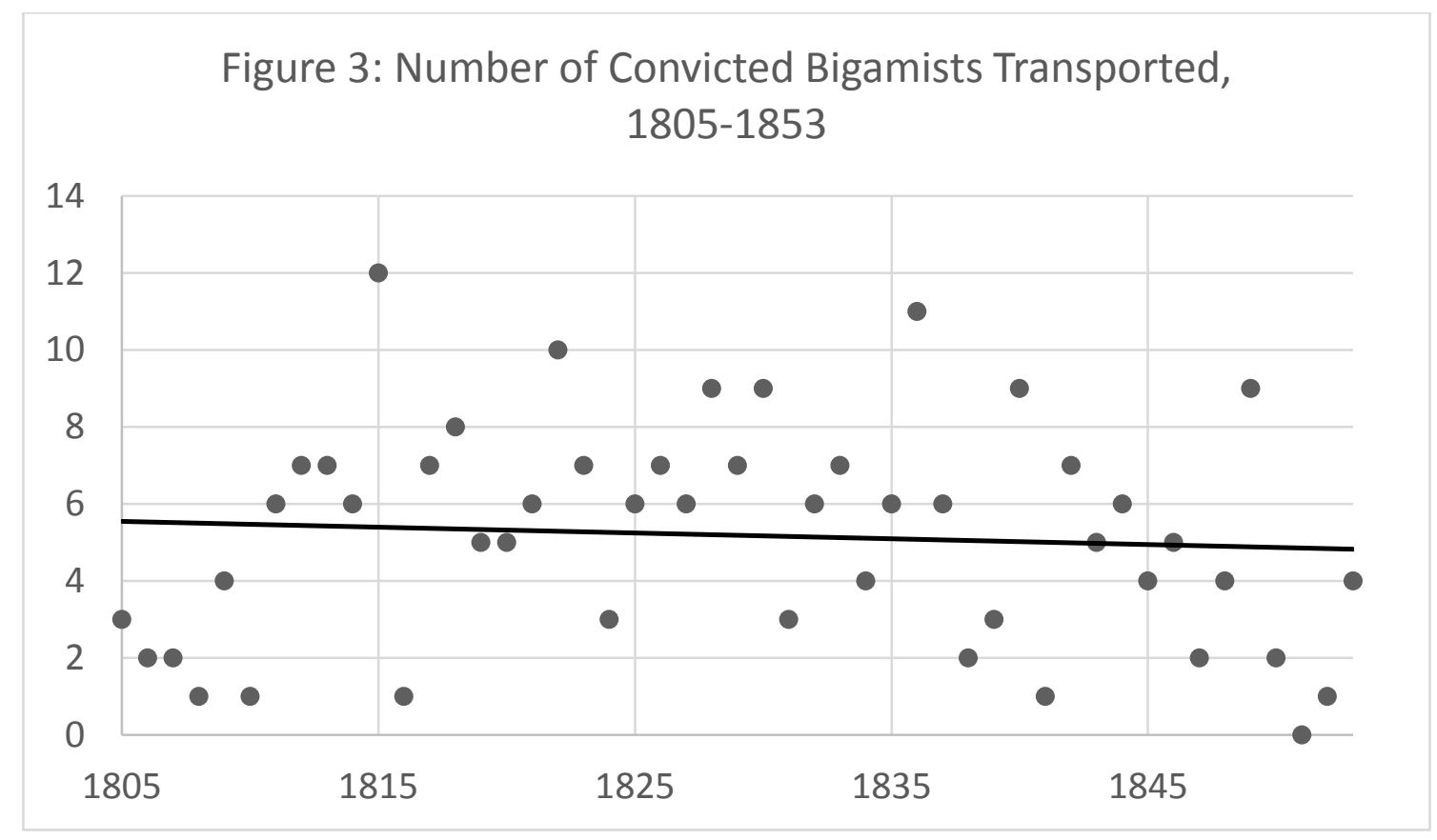

Of course, this does have to be viewed in the context of the increase in population: a broadly horizontal trend obviously represents a decrease in real terms. The question then arises: was there a particular type of bigamy that was always likely to result in a sentence of transportation, or did perceptions of the seriousness of the crime change over time? In order to answer these points, it is necessary to look more closely at the behaviour of those who were sentenced to transportation.

\section{WHY WERE SOME INDIVIDUALS SENTENCED TO TRANSPORTATION?}

While the criminal registers can tell us who was punished — and how — they cast no light on why particular sentences were handed down. In order to gain as full an understanding as possible of the factors influencing the use of transportation, this section draws on the Proceedings of the Old Bailey and the reports of bigamy cases in local and national newspapers from the period. Both sources provide a rich (if not unproblematic) insight into the punishment of bigamy. 
Between January 1805 and December 1853, some 476 individuals were prosecuted for bigamy at the Old Bailey, of whom 390 were convicted and ninety-eight sentenced to transportation. Given that the Old Bailey accounted for around a quarter of all bigamy trials in the first half of the nineteenth century — and more than half of all cases in 1828 and 1831 - its Proceedings are clearly a key source. Less than a quarter of those tried had pleaded guilty, and even where there was a guilty plea there is occasionally a snippet of information that gives some insight into the sentence. Admittedly, teasing out what had happened in the case from the often-elliptical answers given by witnesses is not always an easy task. Reading the Proceedings in conjunction with the newspaper reports, however, provides both clarification of the import of the questions and reassurance as to the reliability of the reportage.

The latter point is particularly important where the newspapers are the main source of information as to what happened in a particular trial. Given the patchiness of the surviving records, and the impracticality of visiting every local record office in England and Wales to uncover what is often merely a handful of cases, using newspaper reports is the best means of getting an insight into the cases decided at the assizes. A systematic search ${ }^{43}$ of the database of newspapers digitised by the British Library yielded reports of 825 bigamy trials at the assizes over the same period, sixty-two of which involved transportation, as well as additional insights into the cases heard at the Old Bailey. The risk of details being fabricated or misreported was addressed by crossreferencing all of the reported cases with the details recorded in the criminal registers.

\footnotetext{
${ }^{43}$ We searched for 'bigam*' to capture the different variations of bigamy, bigamous, bigamist, etc. No further limitations were placed on the search, in order to capture those that did not go to trial as well as those that did.
} 
While there were occasional discrepancies in the names recorded-with phonetic spellings inevitably being much more common in the newspaper reports — and in the exact sentence handed down, these were usually fairly minor, and the sentence of transportation was sufficiently distinct to be correctly recorded. Moreover, the style of reporting was largely factual: the newspapers were providing coverage of the assizes as a whole, rather than of individual sensational cases. ${ }^{44}$

These sources combined mean that we have information on the majority of cases that resulted in transportation. All of the cases from the Proceedings and all of the bigamy trials reported in the newspapers were tabulated for ease of reference. A range of factors were coded in order to analyse their impact on the sentence handed down both singly and in combination with other factors. ${ }^{45}$ These included both potentially mitigating factors (whether the first spouse had left, committed adultery, or been violent; whether there had been a more-or-less mutual separation; whether the first spouse was believed to be dead; and whether the second spouse knew of the prior marriage, or had had sex with the bigamist before the ceremony) and potentially aggravating ones (whether the second marriage had been a mercenary one; whether the bigamist had used an alias; whether the bigamist had deserted the second spouse; and whether there had been a further bigamous marriage).

\footnotetext{
${ }^{44}$ The case of John Wheeler with which we began is a striking exception to this generally more factual style. Some cases did attract more attention and comment, but these formed a small proportion of the total.

${ }^{45}$ These categories became apparent over the course of reading several hundred reports; they are by nature proxies for spectrums of behaviours which vary from case to case, and the combination of factors in any given case means that quantitative analysis will always be subjective to a degree.
} 
Analysing the data in the light of these factors, it is clear that transportation was not ordered lightly. Almost all of the cases can be shown to have at least one of the aggravating factors that were observed in the case of John Wheeler-deception, financial exploitation, the abandonment of the second spouse, and a further bigamous marriageand many exhibited a combination of such factors. ${ }^{46}$ Even where judges were prompted by the number of bigamy cases to declare that they intended to use the punishment of transportation to send a message about the unacceptability of bigamous marriage, the individuals of whom they made an example were invariably those whose cases featured these aggravating factors. ${ }^{47}$

In order to understand the kinds of cases that did result in transportation, it is important to look at how each of the different forms of aggravating behaviour manifested themselves.

\section{Deception}

${ }^{46}$ There are a small number of cases in which there is simply no detail as to why the sentence of transportation was handed down. There are also a few high-profile cases - including those of Robert Lathrop (OBP, 11 Jan. 1815) and William Lolley ( $R v$ William Martin Lolley (1812) Russ. and Ry. 237; 168 E.R. 779) — where the sentence seems to have been motivated in part by the individual's attempt to exploit a legal loop-hole. These exceptional cases raise complex issues of conflicts of laws and will not be considered in this article.

${ }^{47}$ See e.g. Manchester Courier, 21 Dec. 1844, reporting the comments of the judge at the Lancashire Winter Assizes who was 'shocked' by the number of bigamy cases in the calendar and indicated that he intended 'make one severe example with a view to putting a check to the crime'. The individual selected was George Morland, who was alleged to have four wives in total. 
None of those who were transported seem to have been honest with their second spouse; yet a lack of honesty did not by itself lead to such a sentence. ${ }^{48}$ It was generally only where there had been some active misrepresentation — as opposed to an omission — that transportation would be ordered, at least in the absence of other aggravating features. Some adopted an alias in an attempt to hide their true identity. ${ }^{49}$ Many bigamists, while acknowledging that they had been married before, claimed that their first wife had died: ${ }^{50}$ Robert Telford gave an oath to the brother of his second wife that he was 'a free man', ${ }^{51}$ while Thomas Nall went a step further by showing his third wife the gravestone of his first - omitting to mention that there had been an intervening marriage. ${ }^{52}$

If the second wife had trusted the word of her husband against rumour and gossip, his deception was all the worse. On trial at the Old Bailey, George Dennis Smith demanded of his second wife, 'Was you not told by twenty people that I had another wife?' She acknowledged to the court that she had heard a report that he had a wife before they were married, and had asked him about it; he had apparently told her that other

\footnotetext{
${ }^{48}$ This is clear from analysing those cases in which it was established that the second spouse knew of the prior marriage, which constitute only a minority of the total.

${ }^{49}$ See e.g. Bury and Norwich Post, 12 Nov. 1817 (Anthony Armstrong, otherwise John Armstrong); Morning Post, 29 March 1826 (Thomas Jones, otherwise Thomas Thomas); Morning Post, 29 March 1837 (Robert Tindall, alias John Blacker); Hull Packet, 4 Aug. 1848 (Thomas Dutchett, alias James Hindle Duckett, alias James Thomas Hindle Duckett).

${ }^{50}$ See e.g. $O B P, 20$ Feb. 1811 (John Liles); OBP, 11 Jan. 1815 (Francis Bodenham); OBP, 17 April 1822 (John Mackiah Collins); OBP, 2 Jan. 1837 (John Wishart); Leeds Times, 8 June 1839 (Benjamin Holmes); Hull Packet, 2 June 1848 (sailor George Barlow, who claimed that his first wife had died of a cold after falling overboard).

${ }^{51}$ Chester Chronicle, 6 April 1849.

${ }^{52}$ Leeds Mercury, 4 April 1840.
} 
people 'should mind their own affairs - I was not to mind them, but believe him; and I did believe him to be a widower' ${ }^{53}$ Another witness had confirmed that Elizabeth had said 'she would not believe what others said, but would believe him'.

Some bigamists had not merely denied the earlier marriage but deliberately concocted evidence either to conceal it from the second wife or to make it seem that she had known of it. Elizabeth Ann Fawdon gave evidence that she had heard Joseph Smith was a married man, and that she and her mother had accordingly made enquiries: as she reported, 'the next day his wife came, and said she was his landlady for ten years; she knew he had been married, but did not know that he was married now'. ${ }^{4}$ The truth only came to light when a quarrel broke out and the first wife avowed their marriage. ${ }^{55}$ Daniel Heath presented a paper signed by his second wife, apparently dated a few days before their marriage and assuring him that she would 'take no advantage of your having a first wife living, if we are married'. ${ }^{56}$ She, however, gave evidence that she had written this, at his instigation, seven months after their marriage, the paper being backdated. The witnesses for the defence in the trial of John Sommers were adamant that his second wife had been aware of his first marriage, but under cross-examination it was revealed that they had visited him in Newgate, the implication being that they had been coached. ${ }^{57}$ This was to backfire: Mr Justice Grose was reported as saying that Sommers 'appeared... to

\footnotetext{
${ }^{53} O B P, 30$ June 1825.

${ }^{54} O B P, 21$ Feb. 1828

55 The Standard, 11 Feb. 1828.

${ }^{56} O B P, 15$ Jan. 1828.

${ }^{57}$ OBP, 5 Dec. 1798.
} 
have aggravated his original offence by subornation of perjury' and as advising the Recorder 'to inflict the heaviest punishment upon him which the laws allowed'. ${ }^{58}$

The deception and hypocrisy demonstrated by bigamists whose relationships were overlapping, rather than sequential, came in for particular condemnation. William Reed had been 'paying his addresses to the daughter of an inn-keeper in Oxford St' while still living with his first wife. ${ }^{59}$ John Crowley's second wife lived with him until she discovered that he had married a third. ${ }^{60}$ John Pearmain's case was described by the judge as the worst he had ever heard of: his two marriages were just three days apart, with the first taking place by licence while the banns were being called for the second. As the judge commented: 'This argues a deliberate seduction of two women at the same time. It is a case of complicated wickedness and vice, and is a crime against the laws of religion, decency, and morality. What effect punishment may have upon you I cannot tell, but it may have an effect as an example to others' ${ }^{61}$

\footnotetext{
${ }^{58}$ Whitehall Evening Post, 6-8 Dec. 1798.

${ }^{59}$ Bury and Norwich Post, 22 Nov. 1826. See also the case of William Gale Lambert, who was discovered to have been 'making an offer' to one young lady 'to whom he vowed eternal love' at the very time that he was about to be married to another; and who wrote to the parish officer 'in the most love sick language' to seek the restoration of his 'Dear Mary' (although as both of his wives bore this name it is not clear which he meant).

${ }^{60}$ Sheffield \& Rotherham Independent, 16 Dec. 1848 . He had also deceived her by paying someone to impersonate a clergyman and marry them.

${ }^{61}$ Leicester Chronicle, 2 June 1832. See also the case of Joseph Westmoreland, who married a widow who was many years his senior - but who happened to be the proprietress of a beer shop-and then two months later married a young woman 'to whom it appeared, he had been paying his addresses previous to his marriage with the widow' (Preston Chronicle, 13 Aug. 1836; Manchester Times and Gazette, 20 Aug. 1836).
} 
The fact that all of these examples involve men deceiving women does not mean that women did not engage in similar deceptions, but we have traced no case where a woman was transported on this basis alone. As we shall show when analysing the factors that might mitigate the sentence, a woman deceiving a man into a marriage was not regarded as seriously as the reverse. ${ }^{62}$

\section{Financial exploitation}

A significant proportion of bigamous marriages that resulted in a sentence of transportation had involved the financial exploitation of the second spouse. As the Common Sergeant commented in the case of John Crooks, 'if the second wife had property, he added robbery at the altar to the crime of perjury'. ${ }^{63}$ Patrick Cannon was similarly condemned by the court on the basis that his bigamy had been compounded by 'perjury, seduction and robbery', ${ }^{64}$ while in the case of John Steadman the Recorder reportedly observed that the offence 'was one which struck at the very rock of society', involving as it did the 'the ruin of person, property, and in this instance, prosperity'. ${ }^{65}$ The judge in the case of Henry Fountain was somewhat blunter, concluding that 'It is clear what he married for-he got her money. ${ }^{96}$

\footnotetext{
${ }^{62}$ See further below.

${ }^{63}$ Morning Post, 18 Jan. 1822.

${ }^{64}$ Morning Chronicle, 23 Aug. 1820.

${ }^{65}$ Morning Post, 14 May 1836.

${ }^{66}$ North Wales Chronicle, 2 Aug. 1842.
} 
The 'robbery' that a number of judges alluded to in emphasizing the particular harm of these bigamous marriages ${ }^{67}$ was no mere figure of speech. In case after case, the deluded spouse gave evidence that the bigamist had dissipated their property and then abandoned them. Ann Clark told the court that Patrick Cannon had lived with her for just four months after their wedding, 'and having dissipated her little fortune, and reduced her to poverty and wretchedness, deserted her in a state of pregnancy'. ${ }^{68}$ The Morning Post reported how Henry Westerman 'immediately after marrying' his second wife, 'plundered her of her hard earnings, and then left her to the mortifying discovery of his having a former wife living'. ${ }^{69}$ John Caulton was reported as having left his second wife 'almost destitute of the necessities of life' when he left her a month after their marriage, taking with him her gold watch and some money; when arrested, he was living with his first wife. ${ }^{70}$ He had probably decided that his chances of getting any more from his second wife were slim: as she subsequently told the Old Bailey, '[m]y friends intended giving me some property, but they thought they would wait to see how he behaved to me'. ${ }^{71}$ John Major Hallett persuaded his second wife to give him all of her money-around $£ 190$ - just four weeks after their wedding and suggested that she go to visit her sister. When she returned that same evening the house was stripped of its contents and her husband — and the money—gone. ${ }^{72}$ And John Brice was even more blatant, staying with

\footnotetext{
${ }^{67}$ See e.g. Lloyd's Weekly Newspaper, 26 Aug. 1849, reporting the case of John Major Hallett.

${ }^{68}$ Morning Chronicle, 23 Aug. 1820.

${ }^{69}$ Morning Post, 20 July 1809, reporting on his examination at Bow Street a few months before his trial.

${ }^{70}$ Observer, 3 May 1818.

${ }^{71} O B P, 26$ May 1819. Happily, she had been able to retrieve her gold watch from the pawnbrokers.

${ }^{72}$ Morning Post, 10 Aug. 1849; OBP, 20 Aug. 1849.
} 
his second wife just two days after the wedding and then taking both her inheritance of $£ 100$ and her gold watch. ${ }^{73}$

Of course, very few of the women in these cases possessed significant assets. But they nonetheless emphasized that their bigamous husband had taken what they did have. Clothes — which were often pawned to provide ready cash $^{74}$ - featured heavily in their accounts. As the second wife of John Liles explained, 'he took away my clothes, part with my consent; he said he had thirty-two pounds to receive, if I would let him have my clothes he would return them me when he took the money' ${ }^{75}$ The second wife of Samuel Taylor told the court that she 'had furniture and other things' and that Samuel 'took a few of my things, and made away with the chief of my clothes to support himself while he was with me'. ${ }^{76}$ Julia Healey acknowledged that she 'had no fortune' but her evidence that William Guy had 'pawned the ring off my finger and my clothes, and then deserted me' was damning enough. ${ }^{77}$ Others reported that they had a little nest-egg built up from

\footnotetext{
${ }^{73}$ OBP, 12 Sept. 1804; Bury and Norwich Post, 19 Sept. 1804, noting that he had 'married a young woman in order to defraud her of $£ 100$, which she had acquired by the death of a relation'. See also $O B P$, 4 Dec. 1828 (the second wife of James Hall told the court that he had got $£ 100$ of her property before being arrested a few days after their wedding).

${ }^{74}$ See e.g. $O B P, 20$ Sept. 1809 (the second wife of Richard Hemmings complaining that 'he took all my money, and pawned my clothes'); $O B P, 11$ Sept. 1828 (the second wife of John Barclay claiming that 'he made away with my clothes, and the tickets of my property'; he did not deny this but pointed out that 'they did not exceed $£ 2$ in value'.)

${ }^{75} O B P, 20$ Feb. 1811.

${ }^{76} \mathrm{OBP}, 28$ Oct. 1818. See also 10 April 1828 (Ann Deary telling the court that George Foyles 'had pawned some of my things and I have worked very hard to get them out - I had to maintain him; he might do a little work, but what he got he spent').

77 OBP, 9 April 1823 (William Guy).
} 
their savings or an inheritance. Ann Clark told the court that she had saved $£ 8$ in service and had received a further $£ 50$ as a legacy. ${ }^{78}$ Elizabeth Redman and Rachel Parsons had each saved around $£ 20$ in service. ${ }^{79}$ Some women had accumulated an impressive sum of money through their hard work and thrift, which made their unfortunate marriage all the more devastating. Charles Bedson's second wife, who had been a housekeeper 'in several respectable families', reported that her husband 'had about four hundred pounds with me; the savings of my wages during the whole of my life, and I am now so reduced as to be obliged to go to service' ${ }^{80}$

A few cases involved more wealthy heiresses and more calculating fortunehunters. ${ }^{81}$ Thomas Gordon was alleged to have told one acquaintance that 'there was a lady at the west end of the town, possessed of considerable property, if he could get married to her now, but he could not marry for two years, as his first wife had not left him five years' ${ }^{82}$ In the event her $£ 2,000$ led him to risk it. Richard Belcher’s second wife was possessed of around $£ 1,000$. When his first wife turned up he introduced her as his cousin (and in a bizarre twist the three parties ended up living together in the same house even after the second wife had discovered the truth!). Even so, Mr Justice Maule, 'after observing that he could find no extenuation for the fraud he had practised, sentenced him

\footnotetext{
${ }^{78} O B P, 18$ Sept. 1820.

${ }^{79}$ See respectively $O B P, 20$ Sept. 1809 (Henry Westerman 'had $£ 22$ of me, and spent it'); OBP, 6 Dec. 1820 (John Harwood’s second wife had saved around £15-20 in service, and lived with him for three weeks after their wedding until she discovered he was married).

${ }^{80} \mathrm{OBP}, 25$ Oct. 1815.

${ }^{81}$ See e.g. Hull Packet, 13 Sept. 1833, reporting the case of Hiram Holmes, who married his second wife having ascertained that she was 'entitled to $£ 750$, and had the most flattering expectations'.

${ }^{82} O B P, 28$ Oct. 1820.
} 
to the extreme punishment which the law affixes to the offence of bigamy'. ${ }^{83}$ Newcomen Edgeworth was clearly perceived as having ideas above his station, as well as abusing the generosity of those who had helped him, in marrying the widow of his former patron despite his first wife still being alive. ${ }^{84}$ And Michael Farrell conveniently turned up at the home of Elizabeth Cowell just after she had come of age, and into possession of her fortune. ${ }^{85}$ He persuaded her into an immediate marriage, without consulting her relations, vowing that he 'would put an end to his existence' if she did not marry him. ${ }^{86}$ The day after the marriage 'he proposed my going with him to the Bank, and taking out two hundred pounds'. While his new wife had sufficient caution to suggest that a hundred would be sufficient, she still travelled with him to Ireland, where he abandoned her without any money.

In a number of these cases, the bigamist had practised a double deception, attempting to enhance his eligibility by pretending to be possessed of property as well as free to marry. Richard Hemmings won his second wife by telling her that he had $£ 250$. As she told the court, 'I was a servant, I thought I might be comfortable'. ${ }^{87}$ Maria Robinson, the second wife of William Bellamy, told the court that he 'had pretended that he was a moneyed man', and had 'expended a considerable sum of money belonging to her' during the ten days that he remained with her. ${ }^{88}$ Charles Cave represented himself to be a man of property and in this guise courted a Miss Cope, who was entitled to $£ 1,000$

\footnotetext{
${ }^{83}$ Morning Post, 13 July 1843.

${ }^{84} O B P, 26$ Oct. 1814.

${ }^{85}$ According to the Morning Post, 6 Dec. 1813, she had assets worth $£ 800$.

${ }^{86} O B P, 1$ Dec. 1813.

${ }^{87}$ OBP, 20 Sept. 1809.

${ }^{88}$ Morning Chronicle, 1 April 1830.
} 
upon attaining her majority, and whisked her off in a chaise to Gretna Green. It was then discovered that he was only a cooper and had no property, as well as having two earlier wives. $^{89}$

Interestingly, little sympathy was shown to men who had married women for their money even where it was the woman who was the bigamist. William Eagles and Henry Goodman both gave evidence that Hannah Andrews had represented herself as being a woman of wealth before marrying them and running off with their property. The magistrate's unsympathetic response that since 'neither of them married her for love... $[\mathrm{t}]$ hey are both very rightly served $\cdot{ }^{90}$ Nonetheless, the fact that Hannah had compounded her multiple marriages by theft, and appeared in no way contrite, ${ }^{91}$ was presumably a significant factor in her being transported, one of the few female bigamists to receive this sentence at the Old Bailey. ${ }^{92}$

\section{The abandonment of the second spouse}

${ }^{89}$ Observer, 30 Aug. 1824.

${ }^{90}$ Morning Post, 12 Jan. 1829. He was not particularly flattering towards Hannah, either, commenting that 'From her appearance I should not suppose she would get two husbands in three months, unless they took her for the money they supposed she possessed.'

${ }^{91}$ The press reported her as laughing throughout the examination before the magistrates and ogling both of her husbands: Newcastle Courant, 17 Jan. 1829.

${ }^{92} O B P, 15$ Jan. 1829. A similar fate was suffered by Mary Ann Crossley, who had made representations as to her financial expectations to both her second and third husbands. By contrast, Alice Moss, who pretended to have been possessed of property and divorced from her first husband but had only one bigamous husband and was sentenced to six months with hard labour (Hull Packet, 6 Feb. 1846). For the significance of gender as a factor in sentencing, see further below. 
As the cases above illustrate, financial exploitation was often linked with the abandonment of the second wife, with the bigamist moving on as soon as the money was within his control or spent. ${ }^{93}$ Harriet Le Sturgeon, the second wife of Samuel Taylor, had a sad story to relate: after he had lived with her for a couple of months, he 'went out one morning, said he was going to look for work, and never returned-I did not know he was going to leave me' ${ }^{94}$ Her child was subsequently born in the workhouse.

But abandonment was often seen as an aggravating factor even in the absence of financial motives, as it indicated that the second marriage was not a genuine one. Julia Healey told the Old Bailey that William Guy had lived with her for two years before leaving her and their child 'without a penny to buy bread'; he then returned a couple of years but left her once again when she was again 'in the family way'. ${ }^{95}$ George Dennis Smith and Samuel Avery stayed with their second wives for periods of five weeks and one month respectively. ${ }^{96}$ Henry Stanton Pyke-whose chequered career included forgery and embezzlement — deserted his second wife twice when he got into straitened circumstances and was found 'living in style with a lady' ${ }^{97}$

Of course, much depended on why the bigamist left the second spouse. In a few cases it was to return to the first. This was generally viewed as mitigating the offence, but

\footnotetext{
${ }^{93}$ See e.g. The Charter, 28 July 1839 (Joseph Orgill lived with his second wife for six weeks after their marriage and then returned home with the money and watch she had given him).

94 OBP, 28 Oct. 1828.

${ }^{95}$ OBP, 9 April 1823.

${ }^{96} \mathrm{OBP}, 30$ June 1825; 7 April 1825. Contrast the more lenient sentence of two months handed down to Mary Hilton, who had lived with her second husband for more than a decade before leaving him (Bradford Observer, 4 Jan. 1844; Leeds Mercury, 6 Jan. 1844).

${ }^{97}$ Morning Post, 15 Jan. 1849
} 
in the case of William Robson was accompanied by a degree of callousness and hypocrisy that was deemed to aggravate his offence. Having initially decamped, leaving his first wife destitute, and marrying a woman half his age, he then found his first wife begging in the street. Having taken her home and pleaded forgiveness, he then told his second wife to go about her business. ${ }^{98}$ Before the magistrates, he was described as sanctimoniously drawling a "disgusting "left-handed blessing"” on his second wife: "May the blessing of God rest upon you, and may his holy spirit be poured into your heart within three days, and make you a new creature. ${ }^{, 99}$ The magistrates were unimpressed, ordering the police to remove him to cut him short, and his case was later described as an 'aggravated one'. 100

\section{More than one bigamous marriage}

The abandonment of the second spouse was sometimes aggravated still further by the bigamist entering into a third marriage. ${ }^{101}$ John Gynar was reportedly living with a third

\footnotetext{
${ }^{98}$ Bradford \& Wakefield Observer, 1 Oct. 1846.

${ }^{99}$ Leeds Times, 3 Oct 1846, reporting this under the headline 'A Fanatical Bigamist'.

${ }^{100}$ Bradford \& Wakefield Observer, 17 Dec. 1846. A similar level of callousness was displayed by William Conner: asked by his second wife for money he said that 'she was not in distress, that she had got her wedding-ring she could part with' (OBP, 12 Dec. 1836).

101 The following, for example, had all had three wives: Joseph Gardiner (Newcastle Courant, 28 May 1825); Evan Gwillim (OBP, 16 Sept. 1830); James Lewis (Essex Standard, 30 Nov. 1833); William Powell (Sheffield Independent, 3 May 1834); John Oxman (OBP, 8 July 1839); Thomas Smith (Derby Mercury, 16 March 1842).
} 
wife at the time of his arrest, and when he was found guilty Garrow B used the occasion to roundly condemn those who behaved in this way:

the offence of which the prisoner had been convicted was of the most crying nature. Unprincipled men were in the habit of forming matrimonial connexions with young women, and then deserting them in the most heartless and cruel manner to their ruin. Such transactions called loudly for the utmost vengeance of the law. ${ }^{102}$

Not all of these additional marriages were formally tried as separate counts of bigamy. The second wife of Robert Fenton mentioned in her evidence that he 'was not found by me, but by his third wife'. ${ }^{103}$ Counsel had apparently 'proposed to have the prisoner tried on another indictment for marrying a third wife, under circumstances of the most shocking baseness'; the judge 'thought it unnecessary to proceed to a second trial... but told the prisoner that he could expect the severest punishment the law could inflict'. ${ }^{104}$ William Egerton Stafford challenged the prosecution to provide proof of the third and fourth wives that he was alleged to have married: the judge, however, simply noted that 'there was sufficient proof of his having had two wives, by whom he had had children, and he would not punish him for marrying the two last females, but give him the full punishment allowed by the Act'. ${ }^{105}$ In other aggravated cases, the bigamist had managed to secure an acquittal in relation to one of multiple marriages on the basis of some

\footnotetext{
${ }^{102}$ Morning Chronicle, 7 Dec. 1822.

${ }^{103}$ OBP, 30 Nov. 1808.

${ }^{104}$ Bury and Norwich Post, 7 Dec. 1808.

${ }^{105}$ Morning Post, 6 April 1833.
} 
technicality. Thomas Mills, for example, was indicted three times for bigamy. On the first two occasions he was acquitted on the basis that his first marriage was deemed to be void ${ }^{106}$ three months later he was finally convicted on the basis of his second and third marriages. ${ }^{107}$

Multiple relationships also counted against female bigamists. Multiple bigamist Mary Clay was sentenced to fourteen years' transportation, ${ }^{108}$ and the double bigamies of Hannah Goodman and Mary Ann Crossley were clearly significant factors in their sentences of transportation. ${ }^{109}$ Elizabeth Wood Lloyd's somewhat chequered sexual history seems to have counted against her even though she had only committed bigamy once. Her first husband was aggrieved by her getting rather too friendly with one Captain Bligh while they were all drinking together. As one witness recalled, he told her that "If you like the sailor better than me, you had better go with him;" the sailor then threw $5 \mathrm{~s}$. on the table, and he and the prisoner went off together, and left me and Lloyd to drink the gin'. ${ }^{110}$ After Bligh's death she married again, her first husband still being alive, but was subsequently discovered in bed with a Captain Atkinson.

${ }^{106} O B P, 5$ April 1827. His first marriage had taken place while he was underage and without the consent of his parents.

${ }^{107} O B P, 12$ July 1827.

108 Criminal Registers, HO 27/46, p 423; Hull Packet, 8 March 1833.

${ }^{109}$ See above.

${ }^{110}$ OBP, 4 Dec. 1828. 
Where two counts of bigamy were established against the accused, the court would on occasion order a double sentence. ${ }^{111}$ William Gale Lambert—who also passed under the name of William Leonard Robert Gale-was found guilty on two separate charges of bigamy and sentenced to two terms of seven years. ${ }^{112}$ So too was William Skilton, although in his case there were alleged to be two earlier marriages as well. ${ }^{113}$ Skilton had also compounded his two bigamous marriages by violence, and threatened to make his second wife 'hold her noise' when she castigated him as 'a blackguard'. ${ }^{114}$ The fact that James Scotchmore had committed his two bigamous marriages for financial gain was seen as an aggravating factor justifying his sentence of fourteen years' transportation. $^{115}$

In other cases, there is nothing on the record to hint at the existence of an additional—and aggravating — marriage, but it has come to light by other means. Thomas Parmiter, convicted at the Old Bailey in $1815,{ }^{116}$ may well have been advised to plead guilty, since it was apparent that his would be regarded as an aggravated case. The fact that his three marriages had taken place in a relatively short period — the first in March

\footnotetext{
111 This was not necessarily two sentences of transportation: see eg Henry Gatehouse, who received six months for his first offence and seven years transportation for his second: Bury and Norwich Post, 12 April 1843.

${ }^{112}$ Ipswich Journal, 16 April 1836. See also the case of George Ward, convicted at the Nottingham
} Assizes in 1844 after having been convicted of the same offence the previous year: Derby Mercury, 20 March 1844.

${ }^{113}$ Morning Chronicle, 2 Nov 1829.

${ }^{114}$ OBP, 29 Oct. 1829.

${ }^{115}$ Daily News, 20 Sept. 1849; OBP, 17 Sept. 1849. He had also tried to strangle the second wife: Daily News, 9 Aug. 1849.

${ }^{116} O B P, 21$ June 1815. 
1812, the second in July 1814, and the third in January 1815-would certainly have counted against him. ${ }^{117}$ So too would the fact that he had taken out a licence to marry the woman who would eventually become his third wife before he married his second, even though he did not in fact go through with it at that point. ${ }^{118}$ Admittedly, in Parmiter's case there does not seem to have been any deception in relation to the third wife, who, in a complex twist, acted as witness to the second marriage, but this simply deepened the deception practised on the second wife. Given his financial difficulties, ${ }^{119}$ it was also likely that a mercenary motive would have been suggested, and his status as a doctor meant that he was unlikely to receive any sympathy from the court. As it was, the court sentenced him to transportation anyway. ${ }^{120}$

A few bigamists had gone on to accumulate multiple spouses. The many marriages of Edward Jarvis came to light when he was charged with an assault on the niece of his latest wife, who had been trying to prevent him from carrying off her aunt's

\footnotetext{
${ }^{117}$ Parmiter took out a marriage licence on 11 March 1812 and the following day married Elizabeth Massey at St Marylebone, then Rachel Martha Woods at St Leonard's, Shoreditch, on 23 July 1814, and Bridget Mitchell at St Nicholas, Liverpool, on 3 Jan. 1815.

${ }^{118}$ He had taken out a licence to marry Bridget Mitchell on 13 March 1813.

${ }^{119}$ In May 1812 he had been committed to the King's Bench Prison for ten days as an 'insolvent debtor', and on 4 Aug. 1812 he is recorded amongst insolvent debtors who were serving time in prison for nonpayment of debts not exceeding $£ 2,000$.

${ }^{120}$ He duly arrived in Port Jackson, New South Wales, in Jan. 1816 and entered into a further marriage in Windsor, 30 miles inland, later that year. Among his descendants is the Australian chef Maggie Beer, and his story was only uncovered as part of BBC TV's Who Do You Think You Are?
} 
property. ${ }^{121}$ Dubbed a 'Lothario' ${ }^{122}$ and 'this pious Bluebeard' ${ }^{123}$ by the press, his case attracted considerable public interest. ${ }^{124}$ Only three of his alleged five marriages were established at trial, but this was enough to see him transported for seven years. John Wishart was alleged to have had married six wives, although the Old Bailey trial focused on just two of them. ${ }^{125}$ John Crooks - perhaps one of the most unpleasant bigamists in the sample — was initially charged with stabbing Mary Anne Nelson. It then transpired that she was just one of his three wives still living - there had apparently been four more — and that he had debauched his own daughter. ${ }^{126}$ George Whyley, meanwhile, was apparently on the point of marrying an eighth wife when he was apprehended: his was described as 'one of the most impudent cases of bigamy that ever disgraced this country' ${ }^{127}$

${ }^{121}$ Morning Post, 14 Sept. 1826.

${ }^{122}$ Manchester Guardian, 23 Sept. 1826.

${ }^{123}$ Leeds Mercury, 23 Sept. 1826.

${ }^{124}$ See respectively The Examiner, 17 Sept. 1826 (which also described him as being 'of florid complexion and rather bald... of staid and sober demeanour'); and Leeds Mercury, 23 Sept. 1826. The Morning Chronicle, 23 Sept. 1826, noted the crowds present for his examination before the magistrates.

${ }^{125}$ OBP, 2 Jan. 1837; Morning Post, 5 Jan. 1837. See also Devizes \& Wiltshire Gazette, 13 June 1829, reporting that Thomas Ellis had had six wives, of whom three were still living; and Hampshire Telegraph and Sussex Chronicle, 19 March 1853, reporting the trial of Joseph Wardle at the Gloucester Assizes in 1853: he too had apparently had six wives and had made a practice of obtaining money from them and then deserting them.

${ }^{126}$ Morning Chronicle, 17 Dec. 1821.

${ }^{127}$ Preston Chronicle, 18 April 1840. 


\section{DID AN AGGRAVATING FACTOR ALWAYS LEAD TO TRANSPORTATION?}

It is one thing to say that cases that resulted in a sentence of transportation almost invariably exhibited one or more of the above aggravating features. It would be quite another to claim that one of these aggravating features always resulted in a sentence of transportation. In order to develop a more nuanced analysis of sentencing patterns, we need to examine those cases where a potentially aggravating factor did not lead to the most serious form of sentence.

Focusing on the Old Bailey cases, for which the fullest information is available, we see that between 1805 and 1814 transportation was almost invariably ordered where there was one of these aggravating factors, the only exception being a man whose judgment was respited when he joined up as a soldier. ${ }^{128}$ Between 1815 and 1824 the picture is similar. After 1825 , by contrast, the presence of some mitigating factor was more likely to result in an individual escaping a sentence of transportation even if one of these aggravating factors was also present. This trend became still more pronounced after 1835. This explains why the number of cases of transportation remained static over the period despite the doubling of the population: it was not that there were proportionately fewer aggravated cases, but rather that a wider range of factors were taken into account as mitigating the offence.

${ }^{128}$ OBP, 16 Sept. 1812 (Samuel Pearmund alias West). Another man who had married in different names had not deceived his second wife in so doing, as she was aware that he went by different names: $O B P$, 1 July 1812 (Samuel Shermon alias Brown). 
Some of the cases in which a lesser sentence was handed down can be explained on the basis that the aggravating factor was less pronounced. The fact that the second wife had property did not necessarily mean that this was the motivation for the bigamous marriage, or that she was exploited financially. Henry Hamilton lived with his second wife for two years: her $£ 20$ was used to furnish their home but he seems to have provided financial support as well. ${ }^{129}$ The second wife of John Pavey was possessed of a small annuity, but as there was no indication that he had married her for this reason this did not count as a 'mercenary' marriage. ${ }^{130}$ In this context, gendered expectations of the respective roles of men and women within marriage also influenced how financial depredations were perceived. Men were expected to be providers, not to depend on women for support. Conversely, female bigamists who made off with property at the end of the relationship were treated more leniently. ${ }^{131}$

Similarly, the use of an alias did not necessarily involve the deception of the second spouse. Frederick Hilder's alias of Frederick Hilder Holditch hardly disguised his identity, ${ }^{132}$ while Henry Smith had been passing by the name of George Morris but acknowledged his true name before the bigamous wedding. ${ }^{133}$ Nor was leaving the second

\footnotetext{
${ }^{129} O B P, 25$ Nov. 1844 (nine months).

${ }^{130}$ OBP, 11 Sept. 1822.

${ }^{131}$ See e.g. the case of Ann Susannah Busher, who lived with her second husband for two years before leaving him, having apparently 'sold everything' (OBP, 8 May 1837). Ann was sentenced to six months. Esther Sylvester's second husband similarly claimed that she 'robbed me of wearing-apparel and money, and stripped me of every thing she could' (OBP, 17 Sept. 1838). There were competing accounts before the court as to whether he was aware of her earlier marriage, but even so her sentence of two months was lighter than those handed down to men in similar situations.

${ }^{132}$ OBP, 19 Sept. 1842.

${ }^{133}$ OBP, 25 Oct. 1827.
} 
spouse always morally blameworthy. James Cummings, a soldier, stayed with his second wife for just a week, but this seems to have been because he was called away by his regiment. ${ }^{134}$ In other cases the bigamist returned to their lawful spouse. ${ }^{135}$ Thomas Poole left his second wife two weeks after their marriage and when she went looking for him she discovered him with his first wife. ${ }^{136}$

Even entering into an additional bigamous marriage did not inevitably mean that the case was regarded as an aggravated one: the case of Samuel Shephard, sentenced to three months in 1823, was regarded with some sympathy as both his first and second wives had deserted him. ${ }^{137}$ Generally, though, the fact that an individual had entered into multiple bigamous marriages was almost guaranteed to result in them being transported. Of the twenty-six cases in the 1840s in which a bigamist was not transported despite the presence of one or more of the factors that might indicate an aggravated case, only one involved a bigamist who had entered into more than one bigamous marriage, and in his case the outcome is unclear, since judgement was respited. By contrast, at least seven of the nineteen who were sentenced to transportation at the Old Bailey in the 1840s had entered into more than one bigamous marriage. ${ }^{138}$

${ }^{134} O B P, 9$ May 1842.

${ }^{135}$ See e.g. $O B P, 15$ Sept. 1825 (Thomas Wyatt); OBP, 4 Feb. 1839 (Thomas Gallagher, whose second wife also had property, eighteen months); $O B P, 23$ Feb. 1846 (Samuel West Allabaster, one year).

${ }^{136}$ OBP, 23 Nov. 1840.

${ }^{137}$ OBP, 9 April 1823; Morning Chronicle, 7 April 1823.

${ }^{138}$ OBP, 23 Nov. 1840 (Henry Halford Bottrill); 23 Aug. 1841 (Thomas Williams); 31 Jan. 1842 (Richard Light); 15 June 1846 (Joseph Mortimer); 20 Sept. 1847 (Daniel Sinclair); 27 Nov. 1848 (Henry Bramall); 17 Sept. 1849 (James Scotchmore). 
At the same time, certain factors were also seen as mitigating the offence - at least as long as there had been only one bigamous marriage. The key to understanding the operation of the law in this period is the dual conception of bigamy as both an offence against the institution of marriage ${ }^{139}$ and an offence against the person of the second spouse — or, more specifically, the second wife (rather than the second husband). ${ }^{140}$ From the 1820 s there was a growing tendency to describe the crime of bigamy in terms of the harm to the second wife as the 'victim' of the crime. ${ }^{141}$ Judges would therefore take into

${ }^{139}$ See e.g. the description of the 'mischievous consequence' of bigamy as 'tending to dissolve the most sacred contract which civil society knew' (Morning Post and Gazeteer, 24 September 1802) and the observation that bigamy was a crime 'which in its consequences was the most injurious to civil society, as it went to destroy the sacredness of the marriage contract, out of which all the other relations of society grew' (Morning Post, 14 August 1809).

${ }^{140}$ See e.g. Preston Chronicle, 4 March 1843; Newcastle Courant, 8 March 1844; Lincoln, Rutland \& Stamford Mercury, 15 March 1844; Aris's Birmingham Gazette, 14 Aug. 1848; Trewman's Exeter Flying Post, 26 March 1857.

${ }^{141}$ See e.g. Liverpool Mercury, 11 April 1823 (noting the harm to 'the victim of his second marriage in particular, she not being a lawful wife and her children, if she had any, not being legitimate'); also Morning Post, 6 Feb. 1838, reporting the Recorder as commenting that bigamy destroyed the peace of the 'confiding victim, whose agonies could not be imagined, much less described'. 
account whether the second wife was the party prosecuting, ${ }^{142}$ her motives for doing so, ${ }^{143}$ and any plea for mercy from her would carry considerable weight. ${ }^{144}$

The harm to the second wife was understood to lie in her belief that she was entering into a lawful marriage, and in the damage done to her future prospects in having given up her unmarried status, and often her virginity, in the belief that she was to be lawfully wed. There was also, of course, the fact that any children born to a bigamous marriage were illegitimate. ${ }^{145}$ Conversely, then, if the second wife admitted that she was aware of the first marriage, or had engaged in an earlier sexual relationship, the harm done to her was perceived to be mitigated, and the sentence reduced. Men were not seen as being harmed by having a sexual relationship outside legal marriage, which explains why deceit by female bigamists was regarded less seriously. Given the focus on the second wife, it is also understandable that relatively little weight was given to the reasons why the bigamist had left the first wife. These different forms of mitigation will now be considered in turn.

${ }^{142}$ See e.g. Standard, 26 Nov. 1845 (counsel for the defence emphasized that the prosecution of Thomas Kibble was not from the second wife, but from the vindictiveness of the first wife).

${ }^{143}$ See e.g. Morning Chronicle, 6 Feb. 1847 (the second wife of John Harper, who had left her a couple of years earlier, told the magistrate that she wished to prosecute to protect herself from him and to have her marriage declared void, not to punish him).

${ }^{144}$ See e.g. Caroline Hambling's plea to the court to treat Robert Sams mercifully for the sake of his children and blaming her mother for interfering and separating them: $O B P, 19$ Sept. 1836. Robert was sentenced to nine months despite the seemingly mercenary element to his second marriage. See also OBP, 12 June 1843 (Thomas Gardiner Waite).

${ }^{145}$ See e.g. Lancaster Gazette, 30 Aug. 1828, reporting the judge telling Robert Latimer that he had been guilty of "what was a great offence. A young woman had relied upon it that he was a single man, and had married him; the consequence of that was, that a child which she had by him was illegitimate'. 


\section{The second wife's knowledge of the bigamy}

Those who had knowingly entered into a marriage with a bigamist were not regarded as suffering the same harm as those who had believed that they were validly married. In such cases the bigamist's sentence was correspondingly reduced. This provided a strong incentive to claim that the second wife knew, regardless of whether this was in fact the case. In this respect she was also on trial: her reputation would be materially affected if it was established that she had knowingly consented to entering into a bigamous marriage, rather than being duped. This was reflected in the rather ungallant comment of William Frederick Manvell when he was arrested: that his second wife 'knew he was a married man at the time he married her-it was her fault, not his'. ${ }^{146}$

The impact of a later wife being aware of an earlier marriage can be seen particularly clearly in the case of George Taylor. The magistrate who committed him for trial observed that his was the worst case of bigamy he had ever met with, George having married for a third time since being charged with the offence. ${ }^{147}$ At the Old Bailey, however, his third wife admitted that she had not told the magistrate that she was aware that he had been married before and that his wife was alive. ${ }^{148}$ George was sentenced to six months rather than to transportation. ${ }^{149}$

\footnotetext{
${ }^{146}$ OBP, 5 April 1847.

${ }^{147}$ Morning Post, 6 March 1838.

${ }^{148}$ OBP, 2 April 1838.

${ }^{149}$ Other cases in which bigamists seem to have escaped transportation on the basis of the knowledge of the second spouse despite the presence of one or more aggravating features include $O B P, 13$ Jan. 1825 (Thomas Thompson, whose second wife had property); OBP, 29 May 1828 (Nathan Prosser, who had left
} 


\section{The sexual experience of the second wife}

Regardless of whether or not a second wife was aware of the earlier marriage, she was usually deemed to have suffered less harm if she had not lost her virginity as a result of the bigamous marriage. Some bigamists were detected so quickly that there had not even been time to consummate the marriage. Suspicions were aroused very quickly in the case of Henry Smith, and he was brought before magistrates just a few days after his second marriage. ${ }^{150}$ Cross-examined at his subsequent trial at the Old Bailey, his second wife confirmed that the marriage had not been consummated: 'I prevented it —we dined together, but did not spend a very pleasant day: the reason why we did not sleep together was, because I was not to leave my brother's till the Thursday, and I was very ill. ${ }^{, 151}$ Henry was sentenced to just three months, despite his use of an alias. ${ }^{152}$

In the more usual situation, where the second marriage had been consummated, a common, if distasteful tactic on the part of the accused or their defence counsel was to attempt to establish the prior sexual experience of the second wife. Cross-examination of

his second wife); OBP, 10 June 1844 (John McCann, who told his second wife that he had married her for her money); OBP, 23 Feb. 1846 (Joseph Gibson, whose second wife had property).

${ }^{150}$ Morning Chronicle, 5 Oct. 1827.

${ }^{151} O B P, 25$ Oct. 1827.

${ }^{152}$ As noted above, his lesser sentence may also have been influenced by the fact that he seems to have admitted his real name before the wedding, which perhaps should have acted as a warning to his bride and her family. Edward Sutton was less fortunate, but then he had taken advantage of the feeble mental state of his 19-year-old second wife and committed perjury in obtaining a licence: Lloyd's Weekly Newspaper, 4 Nov. 1849; Daily News, 6 Nov. 1849; OBP, 26 Nov. 1849; Hampshire Advertiser \& Salisbury Guardian, 1 Dec. 1849. 
Maria Jennings, the second wife of Jonathan Reynolds, elicited the fact that she had lived with a gentleman for four-and-a-half years and had had a child by another. ${ }^{153}$ This seems to have been decisive in reducing his sentence to a year-and-half in a case that otherwise had a number of aggravating features. ${ }^{154}$ Similarly, Lydia Emert admitted that she had had a child by another man before marrying Thomas Wright. ${ }^{155}$

Even if the second wife had only ever had sex with the defendant, but had done so before their wedding, this would be regarded as lessening the harm to her, whether they had lived together for a significant period of time prior to the marriage, or only anticipated the nuptials by a few days. Jane Harman had a sad story of being ill-used by John Gregson Buckley before being deserted by him while pregnant: as she told the Old Bailey, 'he left me destitute, and what clothes I had he took from me, without leaving me even a pair of stockings, except what I had on'. ${ }^{156}$ When cross-examined, however, she admitted that she had had sex with him before they were married, although she continued to deny that she knew he was a married man. Mary Elizabeth Lucas similarly admitted that she had had sex with James Purnell before their wedding, and that she had previously

${ }^{153}$ OBP, 21 Feb. 1828; The Standard, 25 Feb. 1828.

${ }^{154}$ Maria had an annuity of $£ 150$ per year—settled on her by one of the gentlemen referred to-and Reynolds had exaggerated his own financial situation when courting her: see Morning Chronicle, 4 Feb. 1828; The Standard, 25 Feb. 1828.

${ }^{155} \mathrm{OBP}, 24$ Nov. 1845. The element of financial exploitation in this case was also relatively minor: while Thomas had forcibly seized her gold watch, 'saying, I was his lawful wife, and what was mine was his', and tearing her dress in the process, she had not lost it altogether as it was in the custody of the policeman who had arrested him.

${ }^{156}$ OBP, 2 April 1838. 
not only visited the house where he was living with his first wife but had agreed to be godmother to their child. ${ }^{157}$

The gendered nature of the harm to the person is also evident in the fact that no reference was made in any of the cases to a man suffering any harm of this kind as a result of entering into a bigamous marriage, ${ }^{158}$ even where he was considerably younger and less experienced than the woman. A marriage with a woman of lower social status and doubtful morals might be described as 'unfortunate', but since the formative sexual experiences of many young men took place with exactly such women, the invalidity of the marriage was if anything an advantage.

\section{The limited relevance of what had happened to the first marriage}

In light of the focus in the divorce literature on men whose wives had been faithless or left them, ${ }^{159}$ it is worth noting that pleas that a first wife had behaved badly did not necessarily save a male bigamist from being transported. Given that bigamy was conceived as an offence against the second spouse, it is easy to understand why the conduct of the first was irrelevant, and judges frequently made this point. Thomas Sale Denby pleaded that his first wife had eloped with another man, but was tartly informed

\footnotetext{
$157 O B P, 29$ Oct. 1849. She continued to deny knowing that he was a married man, but in the circumstances this seems unlikely. James was sentenced to two months despite having used an alias and left his second wife.

${ }^{158}$ There were occasional references to the absence of such allegations: see eg Morning Chronicle, 12 Aug. 1826, noting that it was not suggested that 'any injury had been sustained by any person in consequence of the alleged offence'.

${ }^{159}$ See e.g. Gibson, Dissolving Wedlock, 54, and the sources cited in Probert, 'R v Hall'.
} 
that this 'did not warrant him in bringing ruin and destruction on another female'. ${ }^{160}$ Indeed, accusing one's first wife of adultery or other misbehaviour without sufficient proof might be seen as aggravating the offence: the Recorder 'severely reprobated' John Collins 'in endeavouring to defame the character of his lawful wife, whose property he had squandered'; this, along with his 'seduction and perjury' in the case of his second wife, merited 'the severest sentence which the law annexed to his offence'. ${ }^{161}$

The main exception to this unwillingness to look at the circumstances of the first marriage was if the first had been forced and had never existed in any real sense. These were not the arranged matches of the elite but those instigated by the parish where a woman was pregnant. ${ }^{162}$ Such compelled unions ran counter to the firm belief that a marriage should be based on the free consent of the parties. Eighteen-year-old Josiah Thornton was about to marry Hannah Pearson when he was apprehended by the parish officials of Matlock and forced to marry Anna Knowles, who was carrying his child. Two days later he married Hannah as planned and, the day after, he was arrested. ${ }^{163}$ As The Morning Chronicle noted:

\footnotetext{
${ }^{160}$ Morning Post, 31 May 1822. See also OBP, 22 May 1822.

${ }^{161}$ Morning Post, 25 April 1822. See also Joseph Irwin's unsuccessful defence that his first wife was a prostitute and that his second had taken his property $(O B P, 22$ Oct. 1823); Charles Bingham's claimcontradicted by witnesses - that his first wife was a 'a drunken debauched girl' (OBP, 2 July 1849).

${ }^{162}$ For the various sanctions available to parishes see Samantha Williams, 'The maintenance of bastard children in London, 1790-1834', 69(3) Economic History Review (2016), 945.

${ }^{163}$ Chester Chronicle, 24 July 1829; Chester Chronicle, 4 Sept. 1829; Standard, 5 Sept. 1829. He was subsequently sentenced to two years' imprisonment.
} 
The case was said to be one of great aggravation; but, with the leave of those who so term it, we should rather blame the system of compulsory marriage than the luckless lad whom it has led into disgrace and suffering. If the sacredness of the nuptial tie be an essential part of the social system, individuals must be left spontaneously to contract that tie, and free from all other bias than their own inclinations. The law which holds out either menace or temptation to marriage, and then punishes a breach of the forced obligation, is an instrument of cruelty and tyranny. ${ }^{164}$

In a similar vein, one judge described the system as 'destructive of the honourable and sacred principles of matrimony, and almost certain to involve the parties in misery, besides being a strong temptation to commit bigamy'. ${ }^{165}$ So the fact that a bigamist had been forced into the first marriage was regarded as some extenuation for a second, even if there were other aggravating features. ${ }^{166}$

By the 1830s we also begin to see occasional cases in which the conduct of the first spouse seems to have led the court to regard an otherwise aggravated case with more sympathy. Robert Arnell's second wife told the court that she had been possessed of nearly $£ 200$ per annum when he courted her, representing himself as a gentleman. ${ }^{167}$ But

\footnotetext{
${ }^{164}$ Morning Chronicle, 8 Sept. 1829.

${ }^{165}$ Bury and Norwich Post, 17 Aug. 1807.

${ }^{166}$ See e.g. OBP, 15 May 1834 (James Keen, who had used an alias); Liverpool Mercury, 11 Dec. 1846

(Susan Fielding, whose first husband never lived with her as he had been compelled to marry her, whose second left her when he learned of her history, and whose third seems to have married her to look after his family).

${ }^{167}$ OBP, 3 July 1837.
} 
as Robert explained in his defence, he had been separated from his first wife for some years, by a formal deed of separation that acknowledged her relationship with another man, and he considered that he was 'placed in a situation to marry again'. The court did not agree, finding him guilty and sentencing him to a year in prison, but his case was otherwise the kind that would have resulted in transportation. ${ }^{168}$ The Recorder similarly noted that there were 'mitigating circumstances' in the case of Thomas Kibble, despite the fact that he had used an alias when he married his young second wife, there having been reports of his first wife going to Australia with another man. ${ }^{169}$ But it was only in the 1850 s, as the campaign for divorce increased, that claims as to the bad behaviour of the first wife were likely to have a real impact on the sentence awarded. ${ }^{170}$

Unsurprisingly, such claims about the conduct of the first spouse were always less likely to succeed in cases of multiple bigamy. To have had one bad marriage might be counted a misfortune; claims to have had two started to look like a cynical attempt to shift the blame. Thus in the case of William Haywood-alias Yarwood alias William Astley Smith — at the Lincoln Assizes in 1844, his long statement attributing his actions to his first two wives did not save him from transportation. The judge reprimanded his conduct in very strong terms, noting that the court knew nothing of the conduct of the first wives, and that he had brought suffering upon not two but three unfortunate women. He was transported for each offence. ${ }^{171}$

\footnotetext{
${ }^{168}$ See also $O B P, 13$ May 1839 (William Potter, who had used the alias William Goodwin, but whose first wife had had a child by another man in his absence, sentenced to six months in prison).

${ }^{169}$ Standard, 26 Nov. 1845. In addition, as noted above, his second wife was not responsible for prosecuting him: see Morning Post, 3 Nov. 1845.

${ }^{170}$ See further Probert, 'R v Hall'.

${ }^{171}$ Lincoln, Rutland \& Stamford Mercury, 15 March 1844.
} 


\section{PUNISHMENT AND PREVALENCE}

From one perspective, the fact that those who were transported for bigamy had generally aggravated their offence by deception, financial exploitation, abandoning the second spouse, or an additional marriage is hardly surprising. As noted above, the number of such cases remained relatively static over the period, which in the light of the increase in population would represent a real decline in their incidence. Yet once we add in other cases in which there was an aggravating factor that did not result in transportation, we can see that it is the judicial response that changed, not the incidence of aggravated cases.

Given that the overall number of bigamy cases increased at broadly double the rate of population, while the overall number of cases with aggravating factors rose broadly in line with population, this suggests that there was an increase in those cases in which bigamy involved an honest attempt to form a new relationship. This does not necessarily mean that these bigamists were totally open with their second spouses, merely than they did not engage in the more egregious forms of deception discussed above, had not remarried for mercenary reasons, and did not abandon the second spouse for a third.

Of course, the fact that there was a growing number and proportion of nonaggravated cases being prosecuted does not necessarily mean that there was an increase in people committing bigamy. The number of prosecutions for bigamy may be affected by factors other than its incidence. But there is a telling piece of evidence from a small study that we have carried out, asking family historians for details of ancestors who committed bigamy but were never prosecuted. The bigamous marriages revealed in the study were far more likely to have taken place in the 1840 s and 1850 s than in the previous three decades. While there are many factors that might skew this data, it is at least worthy 
of note that the trends in the number of prosecuted and unprosecuted cases are broadly consistent.

Mapping these trends against the likelihood of transportation, it does seem that the number of prosecutions for bigamy was increasing as the likelihood of transportation was receding. It is clearly impossible to ascertain whether the threat of transportation did deter individuals from committing bigamy. It is however worth noting how judges might imply that transportation was the norm and that any lighter sentence actually awarded was an exception. At the Warwick Assizes in 1850, for example, the judge expressed his belief that he ought to sentence Eliza Bolton to transportation, but 'hoped he might with a good conscience inflict a milder punishment, but which should act as a warning to the prisoner and all others inclined to disregard the marriage vow'. ${ }^{172}$ In the same year, we find the Common Serjeant commenting that the case of Thomas Bevan was 'one of the cases where the court might depart from the rule laid down, to transport in bigamy cases'. ${ }^{173}$ As late as 1853 , the judge sentencing Thomas Digby Delamotte noted that he would 'usually' order transportation - albeit in the context of a particularly nasty casebut that this would be useless considering the prisoner was 70 years of age. ${ }^{174}$

Magistrates similarly emphasised the risk of transportation when individuals enquired whether they could remarry. At the Rochester police court in 1853, a former

${ }^{172}$ Daily News, 6 April 1850.

${ }^{173}$ Daily News, 6 Feb. 1850. His reasons were that there was no evidence that he had treated his first wife badly, he had treated his second wife well, and 'there did not seem to be much money or much beauty gained by the second marriage'.

${ }^{174}$ Morning Chronicle, 8 July 1853. The second marriage had been entered into for mercenary reasons, and Thomas had also mistreated his second wife. The Leeds Mercury, 18 June 1853, casts further light on the case, noting that Thomas had previously been charged with administering poison to her. 
soldier sought advice as to whether he could remarry, his first wife having done so two years after he had departed for India, twenty-two years earlier. Upon being informed that the fact that his wife had committed bigamy was no reason for him to do so, he "very innocently inquired if the magistrate thought "they would give him much" (meaning punishment) if he were to do so, upon which he was informed that he might be transported for a short time'. ${ }^{175}$ In response, the man commented that 'he didn't much like to chance it' and then left the court.

Newspapers reinforced the message that to commit bigamy was to run the risk of transportation, not only in highlighting judicial pronouncements to this effect but also in their own commentary and advice. The Chester Chronicle, reporting on the case of Josiah Thornton, who, as noted above, had married his second wife two days after his first and was equally swiftly arrested, joked that he was 'thus a bachelor, twice a husband, and a prisoner with the prospect of a long sea voyage, in the short space of one week!' ${ }^{176}$ More seriously, The Standard, commenting on the restrictive divorce laws, noted that while it was possible to 'buy the privilege of marrying' for $£ 500$, those men who could not afford a divorce might be transported. ${ }^{177}$ And Lloyd's Weekly Newspaper reminded its correspondents that they ran the risk of being transported if they remarried; ${ }^{178}$ only after

\footnotetext{
${ }^{175}$ Daily News, 25 May 1853.

${ }^{176}$ Chester Chronicle, 24 July 1829.

177 The Standard, 1 April 1830;

${ }^{178}$ Lloyd's Weekly Newspaper, 22 Aug. 1852: 'B.B. Bigamy is a transportable offence, and is treated with great severity in an aggravated case.' It did however make clear that transportation was not inevitable but depended on the circumstances of the case: Lloyd's, 10 Feb. 1850: 'DAN BULL.—The act was decidedly bigamy. It can be punished by transportation; but the extenuating circumstances are such, that the judge would most likely mitigate it to a short imprisonment.'
} 
1853 did they begin to advise that the maximum sentence was four years' penal servitude. ${ }^{179}$

There is also evidence that individuals did perceive transportation as a risk. Upon being arrested in 1828, James Hall apparently 'trembled exceedingly' and then offered the officers ten pounds each if they would let him go; when they did not accept he offered five pounds more; and upon the officer telling him sternly that he had the documents in his pocket, said 'I am done, I shall be transported'. ${ }^{180}$ William Leaver, arrested a few years later, seems to have been more sanguine at the prospect, commenting that 'the worst they could do was to transport him for seven years, and he should petition the Court to let him go out of the country'. ${ }^{181}$ One of the witnesses in the trial of Esther Silvester at the Old Bailey in 1838 gave evidence of a conversation with her second husband-to-be in which he had told the latter that he was foolish for attempting to marry Esther as 'the woman will get transported if she marries you, without you can prove the first husband is dead' ${ }^{182}$ The second wife of George Lowe-who had proposed that they travel out to the gold regions in Australia together-rather wryly noted she regretted that 'her hopes of going abroad were frustrated, and that he was likely to go out at the Government's

${ }^{179}$ Lloyd's Weekly Newspaper, 14 Jan. 1855; 'Higginbotham: You cannot marry again. If you do, you are liable to be convicted of bigamy, and may be sent for four years' penal servitude.'

${ }^{180} O B P, 3$ Jan. 1833.

${ }^{181} O B P, 3$ Jan. 1833.

${ }^{182} O B P, 17$ Sept. 1838. See also the comments of one of the witnesses in the case of Sarah Huggins: 'I should be very sorry to be as you are, for do you know if they come forward perhaps they may transport you.' (OBP, 1 March 1841). 
expense to that quarter of the globe instead of being accompanied by her to assist at the diggings' ${ }^{183}$

\section{CONCLUSION}

There are many different stories to be told about the crime of bigamy in early nineteenthcentury England and Wales. Our tale of the 'bad' bigamist who was transported is just one of them, but an important one to bear in mind in assessing the nature of the offence. The significant number of cases which resulted in transportation run counter to the standard view of the offence. Similarly, while many bigamists were perhaps more sinned against than sinning, to focus solely on those who were deserted by a faithless first spouse obscures the greed, deceit, and sheer nastiness demonstrated by others.

The dual conceptualization of bigamy as both an offence against the institution of marriage and an offence against the second spouse explains why certain factors were seen as aggravating the offence while others provided some mitigation. The bigamist who was honest with his second wife was still legally guilty, but less culpable in a moral sense. Conversely, the harm to the second wife was all the greater if the bigamist was offering neither a valid marriage nor a genuine relationship - i.e. where the second marriage was short-lived and exploitative. Expectations about the respective roles of men and women within marriage also shaped judicial perceptions of bad behaviour.

Let us then return to the inference that, because the punishment of it was so lenient, therefore bigamy must have been common. The evidence does suggest that there was a relationship between the punishment of bigamy and the number of cases coming

\footnotetext{
${ }^{183}$ Morning Post, 28 July 1852.
} 
before the courts. Over the period, as the likelihood of an individual being transported for bigamy fell, and sentences as a whole became shorter, the numbers tried and convicted increased steadily. But in turn that means we need to reassess the incidence of bigamy in those periods in which it was treated more harshly. For the early decades of the nineteenth century, then, we must revise the assumption that bigamy was treated leniently and should therefore reverse any starting assumption of widespread offending, requiring those suggesting that bigamy was common to provide direct evidence to support such claims. 